Canadian Journal of Higher Education Revue canadienne d'enseignement supérieur

Volume 46, No. 3, 2016, pages $42-58$

\title{
Five Case Studies of Governance in Tertiary Education
}

\author{
Daniel W. Lang \\ Ontario Institute for Studies in Education, University of Toronto
}

\begin{abstract}
Most studies of governance in tertiary education take as their points of reference colleges and universities, with few examining governance in organizations that deliver various other forms of tertiary education. These organizations often have governing boards, but the boards are not necessarily downsized versions of their college and university counterparts. Although some studies classify governing boards into different types, few offer a clear definition of such boards or explain how they actually function in institutional contexts other than colleges and universities. This study examines governance in five small, public, not-for-profit tertiary institutions, each with a board, to determine what the boards look like, how they perform, what is expected of them, and how they are similar to or different from other types of boards in colleges and universities.
\end{abstract}

\section{Résumé}

Comme il existe très peu d'études sur la gouvernance dans les organisations offrant d'autres formes d'enseignement supérieur, la plupart des études sur le sujet prennent comme référence les collèges et les universités. Ces organisations disposent souvent de conseils d'administration, mais ceux-ci ne sont pas nécessairement une version édulcorée des conseils collégiaux et universitaires. Des études classent les conseils d'administration selon différents types, mais peu en offrent une définition claire ni n'expliquent leur véritable fonctionnement dans un contexte institutionnel autre que dans les collèges et les universités. Cette étude se penche sur la gouvernance de cinq petits établissements d'enseignement supérieur publics à but non lucratif ayant chacun un conseil d'administration. Le but est de déterminer ce en quoi ils consistent, leur rendement, quelles attentes on entretient à leur sujet et en quoi ils sont semblables ou différents des autres types de conseils collégiaux et universitaires. 


\section{Introduction}

Modern economists speak of a problem in contract theory called the "principalagent dilemma," which arises whenever one party (a principal) hires another party (an agent) to perform a job, often in the public sector, for a third party. For example: a government might transfer funds to a non-governmental organization to set benchmarks for language training of refugees; or a religious body may raise and transfer funds in order to train priests; or a group of very small institutions may delegate authority to a consortium as their agent.

This is a fundamental problem for institutional governance and explains a great deal of the interest of governments in accountability in the not-for-profit sector. The answer in most cases is to separate governance and management, especially in large organizations in which the principals' agents are professionals. In higher education, this separation is often described as a boundary that, in addition to assigning roles, also defines the scope of institutional autonomy (Jones, 2002). In most Canadian provinces, this boundary is relatively easy to find in college and university charters, some of which set a further boundary between boards and senates.

"Separation of function," which is the term used in law and behavioural economics (Gilson, 2005), is important. When the lines of demarcation are crossed in higher education, concerns and controversies about academic freedom and institutional autonomy almost immediately erupt. At this point, boards are accused of meddling. For colleges and universities, the lines of demarcation between governance and management are drawn well, although their centres of gravity have shifted over time (Kerr \& Gade, 1989) and may be shifting again (Amaral, Jones, \& Karseth, 2002; Lang, 2013). For other organizations within tertiary education, however, the boundaries and demarcations are less certain and less known. For such organizations, the "principal-agent dilemma" may be greater than it is for either public or private colleges and universities. On the one hand, funding for these organizations is often heavily dependent on demonstrations of accountability and responsible governance. On the other hand, because these organizations are often small, with limited resources, they may sometimes tend to rely on members of their boards to perform roles that otherwise would be assigned to managers and other professional staff.

Most scholarly discussions of governance in the tertiary education sector focus on colleges and universities. The emphasis is reasonable because those institutions comprise by far the largest portion of the sector. There is, however, some recognition that smaller, specialised institutions may have different forms of governance. (Carver, 1990; Carver \& Carver, 1997; Murray, 1996). There is already some evidence, for example, that the "working board" model may often be found in such small, specialized institutions (Lang, 2004), but other models may be possible. We also know that size can be a variable factor in governance of not-for-profit institutions. Imagine Canada, an umbrella organization that sets governance standards for charitable and not-for-profit institutions across Canada, organizes standards into three categories according the size of budget and the number of employees (Imagine Canada, 2011).

\section{The Case Studies}

This study examines, as case studies, five small, specialized tertiary institutions in Ontario. Each is not-for-profit. Some are eligible, either directly or indirectly, for public subsidies. 


\section{The Canadian Centre for Language Benchmarks}

The CCLB is located in Ottawa, Canada's capital. The Centre provides a variety of services in the area of assessing facility in the use of the English language by persons whose first language is not English. Its principal clients are public not-for-profit organizations that provide language training to immigrants and refugees. These include, for example, Citizenship and Immigration Canada, TESL Canada, and the Ontario Centre for Language Training and Assessment. The CCLB, however, also serves firms and organizations in the private, for-profit sector that employ immigrants and refugees. Two examples of privatesector clients are JDS-Uniphase and the Canadian Aviation Maintenance Council.

The CCLB has a board of directors and an executive council. The membership of the board ranges between 21 and 23. There is a chair, vice-chair, and secretary-treasurer. Every Canadian province and territory except Newfoundland, New Brunswick, and Prince Edward Island is represented ex officio on the board. Four members of the board are appointed as "Expert Field Members." Other members come mainly from organizations, such as the Canadian Council for Refugees, which are clients of the CCLB.

The board has 11 standing committees, an unusually large number relative to the number of board members available to serve on them. Several of these committees-for example, the Web Site Review Committee and the Communications Committee--relate directly to units within the CCLB administrative structure. The chairs of committees sometimes are the de facto supervisors of CCLB staff. Some committees--for example, the Learner/Outreach Participation Committee and the Canadian Language Benchmarks Committee--are de facto operational units that conduct the business of the CCLB without compensation.

The CCLB has an executive director and between five and eight staff. Some staff are employed episodically on contract in connection with specific projects. At any given time, the Centre may have as many as three unpaid volunteer staff, in addition to "working" members of the board. The CCLB's annual budget ranges around $\$ 500,000$.

\section{Saint Augustine's Seminary}

Saint Augustine's Seminary was founded in 1913 but was not legally incorporated until 1983. The seminary offers a pontifical degree, the Bachelor of Sacred Theology, and a civil degree, the Master of Divinity, for students who either are or are in training to become Roman Catholic priests. It also has a diaconate formation program and offers lay degrees in theological studies. Some of these programs are eligible for operating grants from the Province of Ontario. The seminary usually has about 180 students and about thirty faculty. The annual budget is about $\$ 4.5$ million. The seminary's board has 15 members, of whom eight must be elected; of the eight, at least four must be from the laity. It meets at least four times annually.

A few of the seminary's programs are eligible for provincial funding, but it relies primarily on support from the Archdiocese of Toronto and its parishes. The board's chair, ex officio, is the Archbishop of the Archdiocese of Toronto. The board has five lay members; all other members are in religious orders and otherwise report directly to the archbishop. The board in the period to which the study applies had two standing committees in addition to an executive committee. The Seminary has an academic council, 
which has the power to establish its own by-laws, but in the nearly three decades since incorporation has not done so.

\section{Algoma University College}

At the time of the study, Algoma University College (AUC) was a semi-independent institution with an enrolment that fluctuated between 600 and 700 undergraduate students, all of whom were in Bachelor of Arts or Science programs. AUC's annual budget was about $\$ 8$ million.

Although affiliated with Laurentian University, AUC was then a separate corporate entity with its own board of governors. The college's governance followed the bicameral model that is typical of most Canadian universities. The board had 14 members, plus the president ex officio, as well as a Shingwauk-Anishinaabe Elders Council. In terms of governance, the board also had obligations to the local Shingwauk-Anishinaabe First Nation.

The college was fully eligible for operating and capital grants from the Province of Ontario, and in some cases the Government of Canada. These grants were received directly from government and were allocated under the authority of the board. In academic and student affairs, the authority of the board was subordinate to the board and senate of Laurentian University

The board of governors of AUC met monthly, which was far more frequent than at any of the other case study institutions. Indeed, it was more frequent than at colleges and universities that were several times larger than AUC.

\section{Toronto School of Theology (TST)}

The Toronto School of Theology is a consortium. Consortia are separate corporate entities with their own employees and assets; hence, a consortium is typically governed by a board comprising the chief executive officers of each member institution and the head of the consortium. The size of the board is delimited by the size of the consortium. TST's board is different in several respects. First, it is relatively large: at the time of the study, the board membership was almost three times larger than the number of member institutions. Although the budgets of the member institutions amount to about $\$ 14.7$ million, and they together enrol approximately 950 students, The TST per se is small, with an annual budget of about $\$ 1.6$ million (an additional $\$ 2.3$ million is transferred to the members of the consortium) and only 10 staff.

The TST comprises seven church-related member colleges and several affiliated churchrelated institutions. The TST is formally affiliated with the University of Toronto, with whom it offers several conjoint degrees. The conjoint degrees are eligible for provincial funding and subject to regulations that accompany the funding. TST's board had 20 members. (A recent change in the by-laws reduced this number to 13, a number coincidentally comparable to the other cases studied.) The board meets four times annually.

As a consortium, the TST also plays the role of a "buffer body" (Fielden, 2008) between its member institutions and the University of Toronto. Because TST is a consortium, its board has two classes of voting members. Typical of a consortium, the class of governors who represent the member institutions have de facto veto power over certain areas of governance--for example, the addition of new member institutions or the resig- 
nation of existing members--and the annual budget. A practical effect of the consortial arrangement is that the class of governors who represent the member institutions are both managers--that is, "workers" in the working board sense--and governors.

\section{Canadian College of Naturopathic Medicine}

The Canadian College of Naturopathic Medicine (CCNM) is accredited by the Council of Naturopathic Medical Education and approved by the Minister of Training, Colleges, and Universities, on the recommendation of Ontario's Postsecondary Education Quality Assessment Board. The college is seeking even higher levels of accreditation. The CCNM is incorporated as a not-for-profit institution and relies almost entirely on tuition fees. Of all the case study institutions, the CCNM has the greatest fiscal interest in maintaining and enhancing its reputation.

It has a board of 14. The college has a faculty council; it does not function as a senate. The faculty are unionized. The board's membership is weighted heavily to professional expertise in law and accounting. Its constituency is very specific: the regulated profession that it serves.

Some CCNM faculty conduct private practice in facilities provided by the college. These faculty do not have a financial equity interest in the conduct of the college, but as practicing professionals they do have a business interest. This may explain the preference for a faculty council over a senate. In this sense the CCNM is somewhat like a conservatory of music that provides specialized facilities for private musical instruction.

The college's annual expense budget is about $\$ 15.5 \mathrm{M}$. Unlike any of the other institutions in the case study, the CCNM has an accumulated surplus that is about 13 percent of its expenses. Enrolment increases are planned, but enrolment is typically slightly fewer than 600 .

\section{Research Design}

Governing boards can behave in several different ways and take several different forms. The behaviours are not necessarily determined by the organizational form of the board. If one seeks to test the performance of a governing board, it is important to know beforehand the sorts of behaviour that might be expected. This investigation applies three empirical tests to each case study institution's governance: what does it look like, how does it perform, and what objectives are set for it--in other words, what is the board expected to do. Within the context of each case study, for each of these questions the investigation became: In what way and to what extent was the form of governance peculiar to the size or particular form and role of the five case study tertiary institutions?

\section{What Does It Look Like?}

Governing boards in the public sector may be classified in at least three different ways. The first and perhaps most common classification is to identify boards by the types of institution that they serve. Thus, a board might be described as a university board or a not-for-profit board. Another basis for identification centres on what boards do and how they exercise their authority. Examples of boards that are defined this way are a governing board or a working board. The third definition is based on a board's relationship to management--for example, an administrative board or a management board. 
This taxonomy is not rigid and exclusive, as would be the case in botany, in which each plant species can occupy only one classification. Instead, as various classification schemes or forms of governance have evolved, there has tended to be overlap between them.

Boards may be differentiated by the corporate forms that their respective organizations take (Bowen, 1994; Carver, 1990). This template quickly leads to a distinction between profit and non-profit boards (Bowen, 1994). Non-profit boards may be subdivided further into boards of public organizations that relate directly to a government or government agency, as in the case of Algoma University College, and private boards that oversee organizations that, other than being sanctioned by government, have no direct connection to a government, as in the case of the CCNM.

There are some "in between" templates. For example, Carver (1990) identified a third category--governmental boards--that seems to occupy a position somewhere between a not-for-profit public board and a not-for-profit private board. In this case-the Toronto School of Theology, for example--the board is delegated by government to oversee other organizations in which government has an interest but which the government does not support directly. This arrangement is sometimes called "management by contract” (Lang, 2002; Rekilä,1995).

Another "in between" type of institution may be public and not-for-profit but operating in a market that is created and regulated by government. The CCLB might be regarded as this type of organization in the sense that governments and government agencies are the Centre's most numerous clients.

Public non-profit boards govern corporations chartered to serve charitable or governmental interests, as is clearly the case with the CCLB and Algoma. Their main responsibility is to build and maintain an effective organization within the charter's purpose. Private non-profit boards are similar to public non-profit boards but serve charitable non-governmental interests. Saint Augustine's Seminary and the CNCC fall into the latter category more than into the former. The TST is somewhere in between. The members of the consortium fit the definition of private non-profit, but as a collective the public nonprofit definition fits in terms of the TST relationship with the University of Toronto as a secular and public university, and of eligibility for public funding.

\section{How Does It Perform?}

Governing boards can also be classified in terms of their relationship to the management of their respective organizations (Paquet, Ralston, \& Cardinal, 1989).

Working boards can be understood conceptually but are problematic in practice. They tend to be associated with organizations that have relatively few full-time administrative staff. Members of working boards move back and forth across the boundary between governance and management.

Administrative boards are also closely involved in management. They set priorities for staff and review the latter's work. They are highly, if not exclusively, internally oriented. One could reasonably argue that an administrative board is a working board for an organization with a larger professional staff.

Administrative/management boards are found in organizations that have professional managers. This type of board is concerned with developing and applying management processes (directing, planning, organizing, monitoring, controlling, and evaluating) 
to work being done by staff. The board may establish standing committees and monitor their performance. Administrative/management boards have both an external and an internal orientation. Because of their external orientation, these boards see governance and accountability as parts of their role.

Management/policy boards are also involved in management but not at all levels. They are most active in planning, in reviewing the performance of staff, in developing policies and strategies, and in determining organizational structure. Management/policy boards arbitrate organizational "turf wars." To the extent that they are involved in administration, their activity is associated with longer-term decisions.

A number of case studies of the performance of governing boards generally in the not-for-profit sector indicate the following more generic possibilities for board performance (Murray \& Bradshaw, 1990):

- ratifying boards, in which a highly influential chief executive officer suggests policies and the board's role is to approve them;

- chair-dominated boards, in which a highly influential chief volunteer officer dominates and the other board members follow;

- fractionalized boards, in which divisions about goals lead to board cliques and infighting;

- consensus boards, which comprise non-traditional, anti-hierarchical, highly participatory structures;

- disorganized and apathetic boards, in which no one wields much influence and little is achieved.

\section{What Objectives Are Set for the Board? What Is It Expected To Do?}

This is an area in which there is much scholarly literature, albeit none about small tertiary institutions specifically. Carver (1990), Bowen (1994), Murray (1996), Jones and Skolnik (1997), Concordia (2007), the Association of Governing Boards (2007), and Imagine Canada (2011) have all written extensively about the duties and roles of governing boards in higher education. The Association of Governing Boards' list of duties and responsibilities is the most succinct and comprehensive; the following is a paraphrase:

- institutional mission, strategy, and objectives;

- recruitment and evaluation of the chief executive officer;

- fiscal integrity, including accountability for public subsidies and private endowments;

- assuring evidence of performance and organization in pursuit of institutional plans and priorities;

- engagement of stakeholders and constituents;

- preservation of institutional and academic integrity; and

- management of risk by being informed about challenges and issues that may confront the institution.

\section{Conducting the Research}

The evaluation was extensive. In the case of the CCLB, every member of the staff was interviewed. With one exception, all previous members of the CCLB staff were also 
interviewed. Nine members of the board were interviewed, as were seven consultants who had worked at various times under contract to the CCLB. Over 200 ESL program administrators, instructors, and assessors across Canada were surveyed electronically. A focus group meeting was conducted in Toronto to solicit the views of representatives of ESL teacher-training programs.

In the cases of Saint Augustine's Seminary, Algoma University College, and the Toronto School of Theology, evaluation comprised attendance at every board or committee meeting as a board member for at least one entire annual governance cycle, as well as meetings with managerial staff and with provincial officials whose responsibilities included relations with the institutions. At the time of the study, the CCNM was in the midst of a review by the Postsecondary Education Quality Assessment Board and seeking accreditation, both of which processes generated a great deal of detailed historical and current information, access to all of which was made available without restriction, as were agendas and enclosed documentation for one annual cycle of the board.

In all five cases, the documentation of all meetings of the board, including most meetings held in camera, were available for review and analysis. In reporting results, however, individual institutions are identified only when the basis of the observations or findings was either publicly available or otherwise not regarded as confidential.

\section{Results of the Case Studies}

First and foremost, the study corroborates the prior research (Lang, 2004) that indicates a propensity towards working boards in small, specialized institutions, even in the largest of the cases studied. The strains on governance often posed an organizational dilemma for most of the case study institutions, as governors and managers had to choose among many priorities that, given the institutions' small size, competed for scarce resources. Because priorities were many and resources scarce, some members of boards became involved directly in their organization's management and administration. Some aspects of boards' committee structures directly mirrored the administrative organization of the institutions, as professional staff reported to chairs of board committees as well as to their respective chief executive officers. To the extent that the members of the boards who were involved in management also represented constituencies that their institutions served, two outcomes were assumed to be possible. Crossing the boundaries between governance and management either served accountability by bringing the organizations very close to their constituencies or circumvented accountability by favouring certain constituencies with "insider" status. This was a particular suspicion at the CCLB. At the TST, because it is a consortium, as "insiders" the member institutions were expected to have such status.

Saint Augustine's Seminary did not have a professional administrator who otherwise would be described as a chief financial officer. It now does. However, at the time of study, that role in practical effect was played by two lay members of the board's finance committee, both of whom were senior financial and budget managers in much larger organizations. Another member of the board was the seminary's de facto legal counsel, and another member was the seminary's liaison with the University of Toronto and the provincial government. The CCNM board was also heavily weighted in the direction of accountants and lawyers. 
At TST and Algoma, and also at the seminary, the board regarded some members as in-house experts, almost as consultants. At the CCLB, some board members were involved directly in the day-to-day operation of the institution. At the CCNM, the audit committee's role in particular sometimes crossed the boundary between governance and management, thus mixing the two as an administrative or management/policy board would.

In terms of a typology, do board size and composition make a difference? Carver (1990) seems to see organizations with working boards as very small and with few employees. To Murray (1996) and Imagine Canada (2011), size is a broader concept, defined mainly by the role of the institution, which may also have significant expense budgets. So, even if all the professional staff were to volunteer their time, which might be the case in some organizations run by religious orders, the organization would amount to much more than a charity or civic club.

Carver's view is that working boards can be effective if they, first, understand that governance and management are different roles and, second, keep those roles separate. In other words, they know and respect the boundaries. Murray believes this view to be naive and over-simplified. To him, the key to effectiveness is something along the lines of a careful and deliberate division of labour among all sorts of activities, including governance and management. The essential distinction in Murray's view is not between governance and management; it is between the important and the unimportant. With respect to both views, it is important to note that in each of the case study institutions it was the board itself that defined the boundaries, usually through by-laws. An example that may confirm Murray's view is the extent of engagement of the board in management at Algoma. In its history as an affiliated university-college, Algoma had experienced considerable mistrust and controversy in collective bargaining with faculty and staff, both of which groups believed that the institution at times had been mismanaged. Labour relations thus were extremely important to the performance and cohesion of the institution. The board for that reason from time to time was more involved in decisions about hiring and firing, the creation of new positions, and budgetary details that normally would not be associated with governance. In regard to internal relations that at times fit the definition of turf wars, Algoma's board sometimes performed as a management/policy board, as did the CCLB board.

The sorts of organizations with which the working board model is typically associated often have diverse sources of funding, as do four of the five institutions studied. That is sometimes why they have to rely on a combination of professional and volunteer staff. All not-for-profit boards rely on constituency membership to connect them to their respective communities for the purposes of accountability, responsiveness, and, particularly in the case of small institutions, funding. The CCLB and Saint Augustine's Seminary among the case studies especially exemplify this behaviour.

Micro-management and confusion, both strategic and operational, are real and present dangers for organizations with working boards, regardless of how the boards are defined. This is a broadly held conclusion (Etzioni, 1964; McFarlan, 1999; Mintzberg, 1979). Wood (1992) and Murray (1996) categorize such boards as "meddling." In all five of the institutions studied, governors to at least some extent crossed the line between governance and management.

The tendency of working boards to micro-manage and confuse is in some respects inherent in the composition of their membership. In the case study institutions, there 
were essentially four sorts of board members: lay or "public" members, institutional representatives, constituent representatives, and expert members. Algoma had all four in more or less equal proportions. Being a consortium that was eligible for public funding, TST's board was weighted heavily in the direction of institutional membership and "public" lay membership. The CCNM board was mainly a balance between professional expertise and constituency. In all five organizations, a significant number of members--sometimes as much as half--were volunteers who served pro bono. For larger organizations, this mixture might not be a cause of difficulty and in many cases may be a source of strength to the board and, in turn, the organization. But for smaller organizations, the mixture might have a less salubrious effect.

This might seem counter-intuitive if not downright imprudent. But there is a rationale for lay membership on boards. The rationale has mainly to do with the presence of other types of board membership. Lay membership is a check against monopoly power and vested interests, both of which can arise from institutional and constituent interests, and from expert and professional interests. The basic case for lay membership is that it protects the public interest. That role can be more than a matter of principle for organizations that depend on support from government (Konrad, 1993) or government agencies. This principle applies particularly to the composition of the boards of the CCLB, TST, and Algoma. In the case of the TST, its lay members are formally called "public" members. This nomenclature is noteworthy. Carver (1990) and Scott (2000) have observed that in general, lay members' lack of expertise can make them ineffective. With regard to the governance of colleges and universities generally, their concern may be well founded. But in the tertiary institutions that were studied, "lay" did not always translate into "inexpert." The TST, for example, in seeking nominations for three of its four lay "public" governors, was very specific about the requirements: a lawyer having experience with academic institutions, an individual with experience in academic administration and finance, and an individual with experience in not-for-profit marketing. From this we can theorize that what "lay" means generally in college and university governance is not necessarily what it means in small and specialized tertiary institution governance. Moreover, the particular use of nomenclature in this example implies an intention that the board will follow the "working" model.

To perform well as governors, all boards need some expertise, but this proved to be especially true of all the cases studied, perhaps less so in the case of the TST, where much of its financial expertise resided in its constituent members. This is typical of consortia (Lang, 1975, 2002). The need for expertise explains why working boards often have members who themselves are experts in the very area of activity that their respective organizations occupy. This applied among the case studies especially to the CCLB, the CCNM, and Saint Augustine's Seminary. The last might seem unusual until one recalls that the predominant purpose of the seminary is to prepare students for the priesthood. Two-thirds of the Saint Augustine's board are priests.

Chait and Taylor (1989), however, have pointed out that having expertise is one of the factors that sometimes leads boards to manage instead of govern. The experience of the CCLB exemplified this. Although the intersection of management and governance was blurry and somewhat confused, there was a high degree of contact between the CCLB board and the CCLB staff. There was an especially high degree of contact between the CCLB staff and some of the board committees. All this is what one would expect of 
a working board. The question, however, is whether or not this is the sort of contact that engenders high levels of accountability and performance.

Normally, staff should be accountable only to their supervisors, and the chief executive officer should be accountable only to the board. That is a modus operandi that most boards understand and enforce. The experience of the CCLB suggests, however, that working boards might not have that understanding or, if they do, are incapable of acting on it. To the extent that the "working" members of working boards direct staff, they may be seen as providing sufficient accountability and first-hand measurement of performance. But as some members of the CCLB board indicated in interviews, there was no systematic means of measuring the performance of board members who were also performing as supervisors and staff. This evidence of interaction between staff and governors indicates that the CCLB's board sometimes behaved as an administrative/ management board, albeit not with good results.

A conclusion that can be drawn here about working board is that under certain conditions, the managerial involvement of board members seems to serve--either poorly or well--as an alternative to effective statements of objectives. To reverse an old adage, the CCLB board, as a working board, seems to have operated on a "do as I do, not as I say" basis instead of attending to its governance responsibility for defining mission.

For a period of time, lay members of the Saint Augustine's Seminary board managed as well as governed in the area of financial management. During this period, three business managers moved through an appoint-dismiss revolving door. The head of the seminary, to his credit, acknowledged that as a priest and theological scholar, his expertise was insufficient to manage and evaluate the seminary's financial staff. He deferred to lay board members who had the requisite expertise.

A similar situation arose at Algoma in a lengthy period when the position of vicepresident for administration and finance was vacant for medical reasons. As was typical in Ontario at the time of the study, almost all revenue that arrived at Algoma was determined on the basis of a complex formula that regulated tuition fees as well as grants. Normally the sort of expertise required by this funding arrangement would be found on the management side of the line between it and governance. Instead, it was found fortuitously but not deliberately on the governance side pro tem.

This aspect of the case studies suggests that governing boards of small, specialized institutions tend towards the working board model in areas of activity that are unstable and anomalous. This aligns with one of Chait and Taylor's (1989) explanations of why not-for-profit boards sometimes become involved in operational activities. Does this tendency promote or hinder the performance of boards in doing their duties and meeting the expectations that are held for them? Evidence of both can be found in the case studies.

In the case of the CCLB, crossing the boundaries between governance and management caused confusion and hampered overall performance. There were reasons for this. On the one hand, the board was unclear about mission, strategy, and objectives. This led to staff depending on members of the board for clarifications and interpretations that amounted to management. And the clarifications were not always consistent from board member to board member. On the other hand, of the five cases studied, CCLB's financial circumstances were the most strained. Its mandate, whether clear or not, was severely under-financed. That being the case, it was not surprising that the CCLB was drawn to the 
working board model. Of all the permutations and combinations that are possible in the structure of governance, the working board is the only one that adds to an organization's capacity to produce and deliver. The more dire the financial circumstances become, the more attractive is the working board model, even if--as in the case of the CCLB--the attraction is more seductive than performance enhancing.

The experiences of Saint Augustine's Seminary and AUC were at once similar and dissimilar. They were similar in the sense that the boundary was crossed in order to fill a gap in management. In the case of the seminary, the gap was avoidable, and the board, as governors, could and should have ensured that the managerial head took steps to fill the gap. Ultimately, but some time afterwards, the board revised its by-laws to separate the seminary's leadership into two parts, one ecclesiastical and one temporal, thus assuring managerial expertise in financial and business affairs. Is this an example of a working board as promotion or hindrance? It was hindrance in the sense that the board could have obviated the problem by not allowing it to happen. It finally did. As an interim measure, avoidable or not, the arrangement "worked."

At Algoma, the situation was not avoidable. In this case, one might say that an advantage of a working board in a small institution is that it can serve as a contingency or what an engineer might call a "redundancy." The board was in practical effect a back-up system on the management side of the boundary. Algoma, however, knew where the boundary was and crossed it only as a matter of temporary necessity. The CCLB, on the other hand, did not seem to know where the boundary was. The seminary came to know through experience where the boundary was. In the case of the TST, as would be the case in any consortium, the members or "owners" enforced the boundary.

Self-funding is risky business in the not-for-profit sector. The CCNM, unlike the other four institutions in the study, was self-funded in the sense that it relied almost completely on revenue from tuition fees. It received no public subsidies and had no endowment. Its tuition fees were high, and higher by far than those of any of the other cases studied.

An organization that decides to move ahead with self-funding has to keep two important factors in mind. The first is that self-funding requires sophisticated financial control and information systems to ensure that what is supposed to be self-funded really is. The CCNM board authorized major investments in financial systems, more by far than any of the other cases studied. The second is to ensure that self-funded projects do not expose the organization to unintended liabilities. This is a fundamental duty of all boards but was of extreme importance to the CCNM board. It had a lot of risk to manage, partly because self-funding can have high infrastructure costs that usually are more onerous for small and specialized organizations than for large ones.

All this explains why the CCNM board's membership is heavily weighted towards expertise in accounting, business, and law. More than any of the other institutions in the study, the CCNM board was aware of the boundary between governance and management. CCNM's senior management were very professional and very competent. But in a "sink or swim" fiscal environment, annual decisions about the college's competitive position with respect to tuition fees and other aspects of student finance were so important that expertise from both sides of the boundary was brought to bear. Everybody "worked." Contrary to some fears about not-for-profit boards (McFarlan, 1999), the financial tail did not wag the CCNM dog. 
These examples from the cases studied indicate that working boards, perhaps inherently or perhaps due to external circumstances, have a natural preference for action instead of delegation, as Chait and Taylor (1989) hypothesized. These examples also suggest a modification of Paquet, Ralston, and Cardinal's (1989) classification of governing boards in terms of their relationship to the management of their respective organizations. The modification is that all four categories--working board, administrative board, administrative/management board, and management/policy board--are in the first instance working boards. They differ only in terms of the form that their "work" takes in crossing the boundary between governance and management.

All five of the boards studied fit in one way or another the definition of a working board. How did they fit Murray and Bradshaw's (1990) further classification of board performance? Saint Augustine's Seminary, because of its Roman Catholic ecclesiastical foundations, clearly fit the definition of a chair-dominated board: the diocesan archbishop is the head of the board and is the final authority in all matters involving the formation of priests. The board's final authority pertains to academic and temporal matters. However, one part of Murray and Bradshaw's definition does not apply: it would be incorrect to describe the chair as a volunteer.

The CCLB at the time of the study was a fractionalized board. Murray elsewhere (1997) has used the term confused board, which also could apply in the case of the CCLB. There were differences about mission, goals, and strategy. There was infighting within the board and between the board and the chief executive. Algoma's board worked hard to be a consensus board. It was casual and informal with regard to procedure, which in turn made it highly participative. Sometimes the board's deliberations were so informal that they did not convey finality, and issues that had been putatively resolved at one meeting were reopened at later meetings, as if the previous meeting had never taken place. Its relationship to First Nations communities was unconventional, although from the First Nations' point of view traditional.

None of the five cases studied could even remotely be described as apathetic boards. Reaching back to Adam Smith in the late $18^{\text {th }}$ century may provide an explanation. Here is what Smith said about boards, in the Wealth of Nations (1776):

The directors of such companies . . . being the managers rather of other people's money than of their own, it cannot be well expected that they should watch over it with the same anxious vigilance with which the partners in a private [company] frequently watch over their own. (Book 1, p700)

A simple paraphrase might be that governors who have no or few stakes in the game will soon become indifferent. A defining characteristic of all five of the boards studied is that a significant proportion of their memberships had large stakes in the performance of their respective institutions. In the cases of the TST, Saint Augustine's Seminary, and the CCLB, members with high stakes were much in the majority. At Algoma, the attachment of an Elders Council to the governing board recognized the special stakes of First Nations. Only the CCNM's board, in terms of stakeholders, looked like a conventional board, but even in that case the stakes of the profession served by the college were expressly recognized. The willingness to "work" and the absence of apathy can be at least partly attributed to the stakes held by most members of their boards. 
The CCNM was in some respects a ratifying board. The board was most active in fiduciary matters and in the management of fiscal risk. In those areas it definitely did not fit the description. It would not be correct to say that the CCNM board was ever a "rubber stamp," but in matters that involved programs of instruction, professional qualification and accreditation, and management of academic staff, the board tended to defer to the president. However, in matters that involved the management of risk, particularly the setting of tuition fees and competitive market strategy, the CCNM board tended to behave like a management/policy board.

\section{Conclusion}

Two characteristics stand out in the cases that were studied. First, the working board model is universally prevalent. Whether inadvertently or out of necessity, the boards of the institutions studied crossed the boundary between governance and management. Sometimes the crossing was general and affected many areas of institutional operation. At other times the crossing was specific and limited to particular areas--for example, fiduciary risk management.

There are several different taxonomies that describe models of governance. What this study suggests is that, in addition to confirming the functional existence of working boards, the working board model is higher in the hierarchy of models than previously thought. The administrative board model, for example, is not an alternative to the working board model; instead, it is a subset defining the form that "work" takes.

Second, unicameralism is much more prevalent than bicameralism. Bicameral governance, which is otherwise nearly universal in higher education, evidently does not apply to tertiary education, at least not to small and specialized institutions such as those studied here. Of the five cases studied, only one--Algoma--had a senate. This might have been expected because of Algoma's affiliation with a university that had full-scale bicameral governance. Algoma's senate connected to Laurentian's senate; Algoma's board connected to Laurentian's board. Nevertheless, the presence or absence of a senate evidently had no effect on the tendency of the board toward the working board model. The working board model may itself provide a pragmatic explanation. Working boards functionally involve de facto co-governance, as does bicameral governance, albeit not in the same way.

From these observations, however, we cannot conclude that because the working board model is prevalent it also always improves board performance, or that it does so because it is typically unicameral. In most of the cases studied, it did; in one, it did not, or at least not to the extent that it did in others. Here we can usefully recall what Birnbaum (1989) said about "manifest and latent functions" in university governance. Governance, more particularly the form that governance takes, may be manifest in specific outcomes or performances that it is expected to achieve. Certain manifest forms persist whether or not they meet the expectations held for them. Why do they persist if they do not meet expectations? In the case of colleges and universities, they may do so simply because they comply with government regulations. But they may also persist because they perform latent unrecognized functions that are of value to the institution, perhaps of more value to small, specialized institutions than to colleges and universities. Throughout the literature about governance in higher education there are cardinal warnings that "the board governs and management manages" (Corbett \& Mackay, 2014)--that 
governing boards should draw the boundary line between governance and management and, having identified this line, not cross it. This may be a defining difference between the governance of colleges and universities and of other tertiary institutions. Tertiary institutions, at least those studied here, tolerate and sometimes systematically seek to cross that boundary. They may feel freer to exercise discretion to do so because their governance is less regulated by government. Of course, it is also possible that the working board model is inherently inferior to conventional models in the sense that small institutions, often with limited and marginally adequate funding, rely too heavily but necessarily on board members as substitutes for professional experts whom they otherwise would employ.

In terms of broader theory, the principles of subsidiarity and separation of function may explain what might otherwise be regarded as idiosyncratic and ineffective governance in small tertiary institutions. Subsidiarity, in the case of governance, would hold that decisions should be made at the level best able to make them, as would be the case in a consortium like the Toronto School of Theology. Separation of function, again in the case of governance, would hold that decision makers perform better when they have a stake in the outcome of their decisions (Fama \& Jensen, 1983). This is greater problem in the case of not-for-profit than for-profit organizations. The "unrecognized functions" about which Birnbaum speaks may in small tertiary institutions exemplify their pragmatic way of allowing water to find its own level in drawing the boundary line between governance and management.

Finally, governance, at least in small and specialized tertiary institutions, is not simply a hybrid off-shoot of the governance in colleges and universities. It warrants further study. Whether the working board model promotes or impedes good governance, many of the findings here could apply to other small institutions, including some with bicameral governance.

\section{References}

Amaral, A., Jones, G., \& Karseth B. (2002). Governing higher education: National perspectives on institutional governance. Dordrecht, The Netherlands: Kluwer.

Association of Governing Boards of Universities and Colleges. (2007). AGB statement on board accountability. Washington, DC: Author.

Birnbaum, R. (1989). The latent organizational functions of the academic senate. The Journal of Higher Education, 6o(4), 423-443.

Bowen, W. G. (1994). Inside the boardroom: Governance by directors and trustees. Toronto, ON: John Wiley \& Sons.

Carver, J. (1990). Boards that make a difference: A new design for leadership in nonprofit and public organizations. San Francisco, CA: Jossey-Bass.

Carver. J., \& Carver, M. (1997). Reinventing your board. San Francisco, CA: Jossey-Bass.

Carver, J., \& Mayhew, M. (1994). A new vision of board leadership: Governing the community colleges. Washington, DC: Association of Community College Trustees.

Chait, R., \& Taylor, B. (1989). Charting the territory of nonprofit boards. Harvard Business Review, 89(1), 44-139. 
Concordia University. (2007). Report of the working group on university governance. Montréal, QC: Institute for Governance of Private and Public Organizations.

Corbett, A., \& Mackay, J. (2014). Manual for effective board governance, Toronto, ON: College Centre of Board Excellence.

Duryea, E. D., \& Williams, D. (Eds.). (2000). The academic corporation: A history of college and university governing boards. New York, NY: Taylor \& Francis.

Etzioni, A. (1964). Modern organizations. New York, NY: Prentice-Hall.

Fama. E, \& Jensen, M. (1983). Separation of ownership and control. The Journal of Law and Economics, 26(2), 301-325.

Fielden, John. (2008, March). Global trends in university governance. Washington, DC: The World Bank, Education Working Paper No. 9.

Gilson, R. (2005). Separation and function in corporate law. Columbia Law School, Law and Economics Research Paper Series, Research Paper No. 277.

Imagine Canada. (2011). Standards for Canada's charities and nonprofits. Ottawa, ON: Author.

Jones, G., \& Skolnik. M. (1997). Governing boards in Canadian universities. Review of Higher Education, 2O(3), 277-295.

Jones, G., "The Structure of University Governance in Canada: A Policy Network Approach," in Amaral. A., Jones, G., and Karseth, B., eds. Governing Higher Education: National Perspectives on Institutional Governance. Dordrecht: Kluwer, 2002. Pp. 213-234.

Kerr, C., \& Gade, M. (1989). The guardians. Washington, DC: Association of Governing Boards.

Konrad, A. G. (1993). A green paper on board governance of the colleges of applied arts and technology in Ontario. Toronto, ON: ACAATO.

Lang, D. (1975). The consortium in higher education. Journal of Educational Administration, 33(2), 23-36.

Lang, D. (2002). A lexicon of inter-institutional cooperation. Higher Education, 44(1), 153-183. doi:10.1023/A:1015573429956

Lang, D. (2004). How working boards work--a working paper. Higher Education Perspectives, 1(1), 78-110.

Lang, D. (2013). Incentives in financing higher education. In C. Amrhein \& B. Baron (Eds.), Building success in a global university (pp. 204-236). Bonn, Germany: Lemmens Medien.

McFarlan, F. W. (1999). Don't assume the shoe fits. Harvard Business Review, November-December. Retrieved from https://hbr.org/1999/11/dont-assume-the-shoe-fits

Mintzberg, H. (1979). The structuring of organizations: A synthesis of the research. New York, NY: Prentice-Hall.

Murray, V. (1996). Improving board performance. The Philanthropist, 13(4), 3-37. 
Murray, V. (1997). Book review of Reinventing your board. The Philanthropist, 14 (4), 57-63.

Murray, V., \& Bradshaw, P. (1990). Voluntary sector boards: Patterns of governance. In Proceedings of the 1990 Conference of the Association of Voluntary Action (Vol. 2). London, UK: Centre for Voluntary Organisation.

Paquet, M. A., Ralston, R., \& Cardinal, D. (1989). A handbook for cultural trustees: A guide to the role, responsibilities and functions of boards of trustees of cultural organizations in Canada. Waterloo, ON: University of Waterloo Press.

Rekilä, E. (1995). Contracts as a management instrument: New policies in relationships between the universities and the Ministry of Education. Tertiary Education and Management, 1(1), 76-80.

Scott, K. T. (2000). Creating caring and capable boards: Reclaiming the passion for active trusteeship. San Francisco, CA: Jossey-Bass.

Smith, Adam (1937) The Wealth of Nations, 1776, Cannan Edition, Modern Library: New York, Book 1, p. 700 (Original work published 1776)

Wood, M. (1992). Is governing board behaviour cyclical? Nonprofit Management and Leadership, 3(2), 139-163.

\section{Contact Information}

Daniel W. Lang

Ontario Institute for Studies in Education

University of Toronto

dan.lang@utoronto.ca

Now an emeritus professor at the University of Toronto, Daniel Lang was Senior Policy Advisor to the President, Vice Provost, Planning and Budget, and Vice-President, Computing and Communications. He received a BA and MA from Wesleyan University and a PhD from the University of Toronto. His principal areas of interest are institutional planning and management, finance, accountability, and quality assurance. His current research investigates how, when, and why community college students decide to transfer, the effects of fiscal incentives, the role of informal knowledge in the formation of human capital, and the performance of consortia. 